\title{
OBJECTIVE AUDIOMETRY USING PSYCHOGALVANIC SKIN RESPONSE
}

By

T. YAMADA, M.D.

From the Department of Otolaryngology, Nihon University School of Medicine

(Director: Prof. S. Nakamura, M.D.)

The author conducted experiments with objective audiometry using psychogalvanic skin response, applying endsomatic method with balanced negative feed-back amplifier system. This apparatus could eliminate the disadvantages of exosomatic method which has been in use. Using this apparatus author tested 85 cases ( 7 months-62 years of age) with from normal hearing to severe hearing loss.

The results obtained were as follows:

1) Thirty-six cases, 68 ears (5.1-62 years of age) were tested by both P.G.S.R. audiometry and standard pure tone audiometry. Reliability in these two methods were within $\pm 5 \mathrm{db}$ in $53.2 \%$, and were within $\pm 10 \mathrm{db}$ in $79.8 \%$.

2) Average difference were $6.6 \mathrm{db}$ lower by P.G.S.R. audiometry than standard pure tone audiometry.

3) Eighty-five cases were classfied to three groups:

A) Cases responded to sound and shock and onditioned readily, 45 case, 52.9\%.

B) Cases respoded to sound and shock and difficult or impossible or conditioning was not attempted, or threshold was not measured, 25 cases, $17.6 \%$

C) No response to sound or shock graphically, 15 cases, $17.6 \%$.

4) Difficulty were increased undet three years of age. The "youngest subject successfully examined by P.G.S.R. audiometry was 2 years and 11 months old.

5) P.G.S.R. audiometry was successful in $80.6 \%$ over 10 years, and were successful in $37.0 \%$ under 10 years of age. Rate of successful test was higher in the group with hearing loss, especially in children under 10 years, satisfactory results were obtained in $41.8 \%$.

6) Rate of successful test was not so high in P.G.S.R. audiometry alone. It is desirable to use several tests, such as play audiometry, speech audiometry and etc, so that more statisfactory results are obtained in clinical application.

\section{Psychogalvanic Skin Response による他覚的 嚼力検查法について}

日本大学医学部耳梹咽唉科教哑（主任：中村四郎教授）

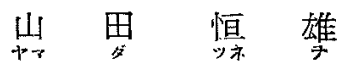

I. 緒 窝

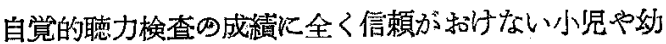
児，または，意志の疏通をかく一部の大人や子供，ある いは僟能的難聴や聴器詐病者などに対して，患者の意志
に古右されることなく，聴加を他覚的に测定して診断の 助けとし，また治療上の方針を泆定することは，臨床的 に極めて重瑟な問題である。殊に難聴児の言語習得や知 的発育を促すためには，なるべく早期にこれらの訓練を 
5ける機会を与えるべきで，5才以後になつては，これ らの社会適応性の訓練を始めるには和告すぎ，㜊くとす 2-守半〜3才㥧からはじめることが望むしいと思わ的る。 ところがこのような年少者の聴力障害の有無を早期に診 断するためにはどうしても他覚的に测定しうる聰力検 查法の出現が必要となつてくる。

他覚的に聴力を測定する臨床的な力法としては，これ までかんたんな startle reflex test をはじめとし, play audiometry や脳波測定の応用，あるい注皮虚電流反射 など、いろいろなすのが工夫され，また現在む研究され つメあるが，それらは，原理的炕は簡単であつても信頼 性がらすかつたり，あるいは実施上代無理な点があつた りして、なかなか私共の希望を渢足させてくれる上らな ものは，見出し難、現状である。しかしこれらのららで 屯, Bordley \& Hardy7) (1949) によつて着目された Pavlov の条件反射及び精神電流反射（psychogalvanic skin response, P.G.S.R.) を応用した方法，すなるら， psychogalvanic skin response audiometry (P.G.S.R.audiometry）は最も合理的であり，李た臨床的応用の 可能性も多いものであると思われるが，その装置の複䧴 さや，検查成績の信頼度，また㞦に白来する各研究者 の成績に不一致な点むみられるので, 私はこの装置にさ
ら火改良を加光，本倹查成續の信頼度を追求し，その臨 床的灾用の価値を検討したので，その結果をこ」に報告 する。

\section{II. 実験装量}

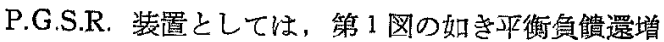
幅方式 balanced negative feed-back amplifier system で，初段，C-R 1 段差動增幅器，2，3，4段，直結 3 段 淔流增幅器を用い, 安定化電源は差動率, $1 \times 10^{-3}$, 時 定数は 1.5 秒である、雪気刺激は 5〜80V 迄可変の蓄電 気放䉓電流である。音源は小林理研製 Model 1002C audiometer 用い，発振周波数は. 125, 250, 500, 1000 ， 2000, 400C, 8000, cps で最低 - 10db, 最高 65 90db

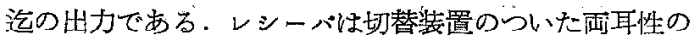
あのをへッドバッドで固定し，又幼児で装着を坡ら者は 同伴者に手で測定耳にあてさせた。記録装置はェスヌー ライン社製ペン害き記録装置を用い，送り速度は1 分間 $75 \mathrm{~mm}$ である. 記録には 2 本のペンを馳動し，そのうち の1 本は P.G.S.R. の記録を，他の 1 本は電気刺激及び 音刺激を同一紙面上に記録し観察を便利にした，電極は P.C.S.R. 用に $1 \times 1 \mathrm{~cm}$ のプシチケ円板電極 2 板を，大 人では手黨及び前膊に，子供では足蹠及び下眼に，電極

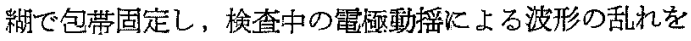

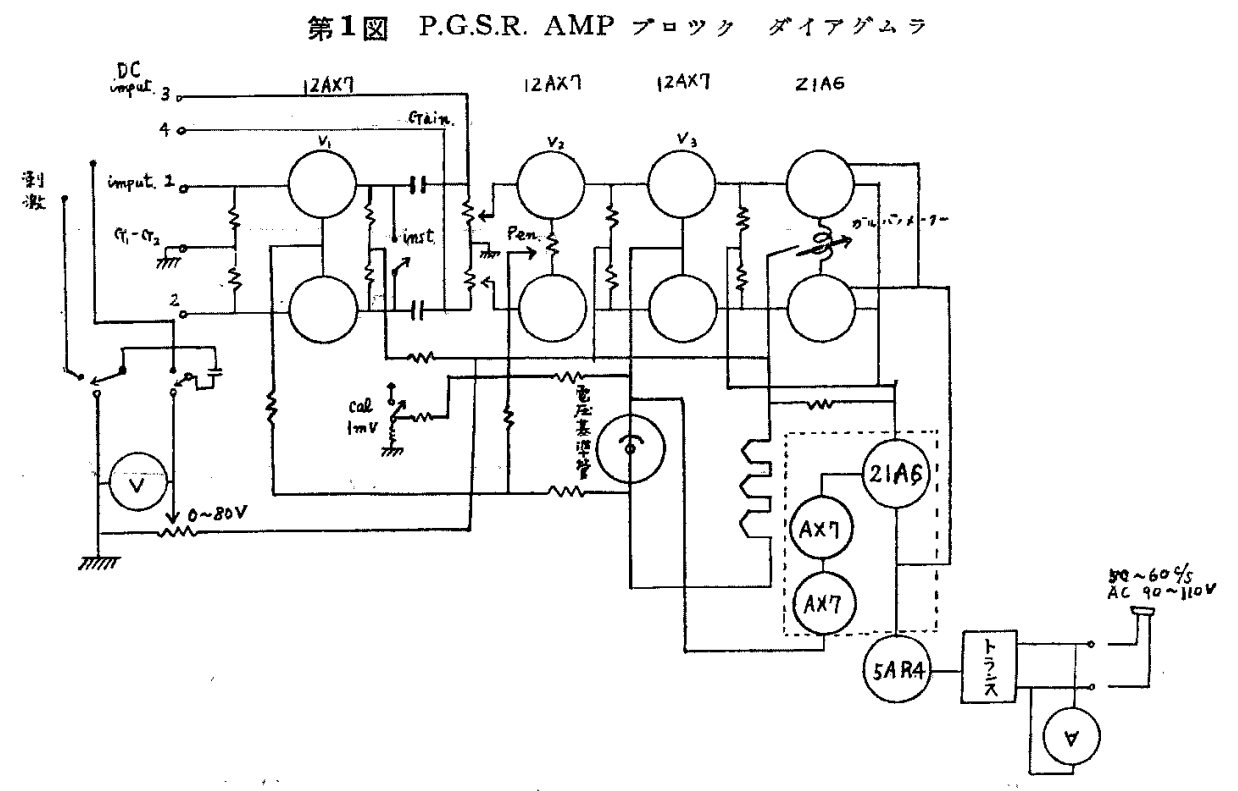

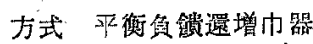

初. 段 $\mathrm{CR} 1$ 段差釛增巾器

2. 3. 4 段 … 直結 3 . 段直流增巾器

安定化電源差動率 $1 \times 10^{-3}$ 
少なくするように力めた．電気刺激用電極は $1.0 \times 1.5 \mathrm{~cm}$ の銀板電槙 2 枚を，大人では指尖又は上䐺に，妙巟では 下腿外側腓腸䉀中央部に附堌した。

\section{III. 実験方法}

実験はすべて，日大医学部耳鼻咽啹科教室の縦横 $3 \times$ $4 \mathrm{~m}$ のシールドされた air conditioning の防音室で行 つた: 室温は大体 $20^{\circ} \mathrm{C}$ 前後に一定L, P.G.S.R. の発 現に充分な条件に保つた。私の用いた P.G.S.R. 記録装 置は 50K 2 ま测定可能なので，測定にさきだら皮发 基本抵抗を測定し参考の一助にした。被椮者が充分に落 清き P.G.S.R. の基線が安定するのを定つて, 被検者に 充分聞元ると思われる条件刺激音を5～8 秒間聞かせ， つで 0.5〜1秒後に 10 30V 迄の無条件刺激である電
気刺澈を与をえた．P.G.S.R. は暗算や音刺激によく反危 することから，急に䈏を聞かせると1〜2秒後に無条件 反射が起るので，これからだけでも残聴の確認になる が，この現かれる反射量の大きさから装置の感度を調節 した．このように; 予め虔膚基本抵抗を湘定した後，条 作つけを開始した. 聴力正常者仙は 1000cps 40 50db, 中等度以下の難㯖之思われるものには $500 \mathrm{cps}$, 又は $1000 \mathrm{cps}$, 70 90db 迄の音を与えた。この上引に音刺激 と電気刺激を続いて与えると，最初は車者に上る反応为う 共に起こるが，通常音刺激による反射は音刺湤を数回く りかえした後には消失し，電気刺激のみの反射が持続す る(第 2 図 A-a, b, c, および B-d, e, f). この場合， 刺激時間及び電気刺激量は適当江調節して，時間条件反
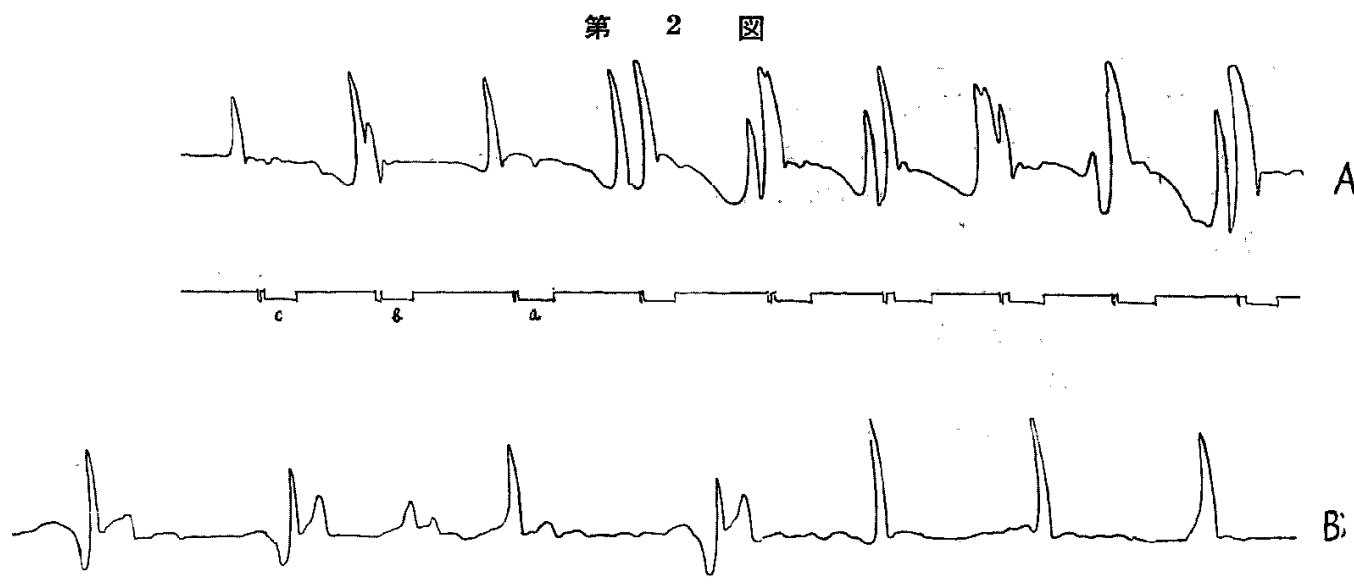

Bi

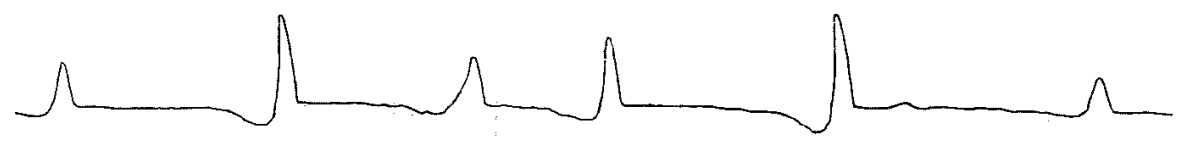

C

\section{(付図説明)}

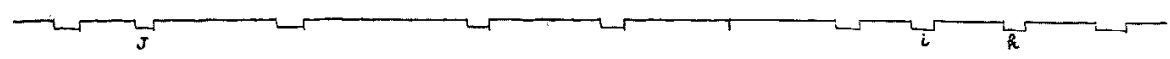

四は，条件反射形成過程の P.G.S.R. の波形で，右から左の方向に向って記録されている．各図の上部の記録: は P.G.S.R. の波形である。下部の矩形波中，巾の広いものは音刺激による音表出時間の長さをしぬす。小さな ダエックは電気制軞の表出をしめす

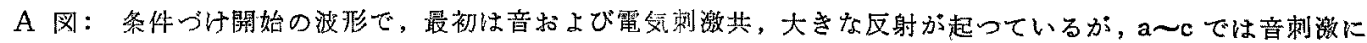
上る反射は消失し，霓気刺激の及の反射が続いている。

$\mathrm{B}$ 図： d f fでは未だ雨気刺激のみの反射であるが，gでは条件反射があらわれてきたことをしめしている。

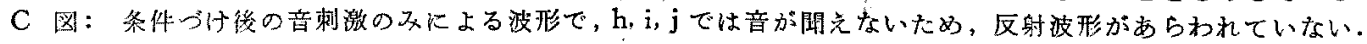


射形成，及びなれによる反射量減退を防ぐことが必要で ある.これを約 10〜20回くり返京すと，条件反射が成 立し（第 2 図、B-g，お上び C) 音刺激だけで充分に反 射が得られる上らになるから（第 2 図，C), 音刺激のみ で, 5 10db, step で音を減弱し闒值を決定した（第 2 図参炤).

しかし，この間值測定の操作中に，反射量が減退し， 剆定に困難索感じた場合には，测定途中にて，更に電気 刺激を与交て，条件づけの強化をはかかた。ささらに子供 では測定に時間がかつる関係上，その測定途中で休みを 与皇たり，子供の興味をひくために，玩具や絵本，キャ ラメル等を与支，泣いたり，あるいはつかれて睡りこむ ことを防ぎ，検查を可能ならしめる上ら努力した。この ため，測定は 30 分〜1 時間以内に終るように力ぬたが， 症例によつては，目的を達成するをでに数日かつるよう な場合もあつた。 また P.G.S.P. の信頼度の比較実験と して自覚的聴力検查が可能な者には，测定前，又はその 後㳊自覚的聴力検查 (standard pure tone audiometry) を同一 audiometer で行ない, 屾検查法による成績を比 較した。

\section{IV 実酸 成繶}

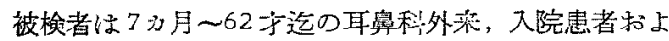
び学生など総数 85 名を対象とした．その年令別と性別 は（第1 表) の如くである。（男:女=2:1）またこれ らの疾患別は（第 2 表）の如くである.

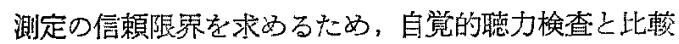

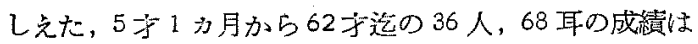
(第3表) の如くで，P.G.S.R.-audiometry の結果が自 覚的㯖力検查の結果より良い場合を( -)，要い場合を (十）とすれば，两渚の差異は， $-15 \mathrm{db} \sim+30 \mathrm{db}$ の籍 囲に分布し，各サイタルに括ける分有状態は表儿見る通 りであるが，信頼限界を各サイタル別に見ると， $125 \mathrm{cps}$ では峏者の一致するものは，23.2\%．土5db の範围のも の 48.2\%.土10db の簕困のもの，75.0\%。.250cps で注 一致忏, $24.6 \%$. $\pm 5 \mathrm{db}, 47.6 \%$. $\pm 10 \mathrm{db}, 75.3 \%$. $500 \mathrm{cps}$

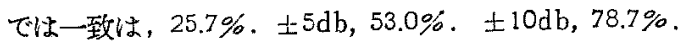

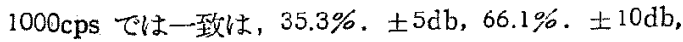
87.6\%。.2000cps では一致は、 $25.4 \%$ 士5 db, 54.2\%。. $\pm 10 \mathrm{db}, 84.7 \%$. 4000 cps では一致は, $24.5 \%$. $\pm 5 \mathrm{db}$ ， $52.6 \%$. $\pm 10 \mathrm{db}, 84.2 \%$. $8000 \mathrm{cps}$ では一致は, $22.4 \%$. $\pm 5 \mathrm{db}, 51.0 \% . \pm 10 \mathrm{db}, 73.4 \%$ となり，これを平均す れば，両者の一致するものは $25.8 \% ， \pm 5 \mathrm{db}$ 以内にと

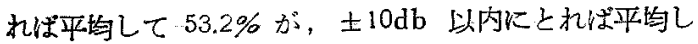

第 1 表 年令及び性别浐

\begin{tabular}{|c|c|c|c|}
\hline 年令别 性别 & 男 & 女 & 計 \\
\hline $0.7 \sim 1.0$ & 3 & 2 & 5 \\
\hline $1.1 \sim 2.0$ & 2 & 4 & 6 \\
\hline $2.1 \sim 3.0$ & 6 & 4 & 10 \\
\hline $3.1 \sim 4.0$ & 5 & 2 & 7 \\
\hline $4.1 \sim 5.0$ & 3 & 1 & 4 \\
\hline $5.1 \sim 6.0$ & 6 & 2 & 8 \\
\hline $6.1 \sim 7.0$ & 2 & 0 & 2 \\
\hline $7.1 \sim 8.0$ & 4 & 1 & 5 \\
\hline $8.1 \sim 9.0$ & 3 & 1 & 4 \\
\hline $9.1 \sim 10.0$ & 2 & 1 & 3 \\
\hline $10.1 \sim 15.0$ & 1 & 2 & 3 \\
\hline $15.1 \sim 200$ & 5 & 2 & 7 \\
\hline $20.1 \sim 62.0$ & 16 & 5 & 21 \\
\hline 總 計 & 58 人 & 27 人 & 85 \\
\hline
\end{tabular}

第 2 表 疾患別分類表

\begin{tabular}{|c|c|}
\hline 正常者（耳庆鬼的来者） & 21 \\
\hline 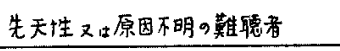 & 33 \\
\hline 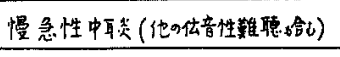 & 7 \\
\hline S.M.性蜼㴔 & 6 \\
\hline 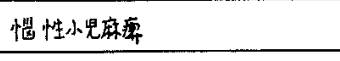 & 4 \\
\hline$x=$ ニ病 & 3 \\
\hline 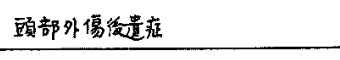 & 2 \\
\hline 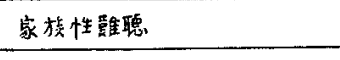 & 1 \\
\hline 小耳症 & 1 \\
\hline Epilepsice & 1 \\
\hline 外像性A A hasie & 1 \\
\hline 先天性梅毒 & 1 \\
\hline 先天性登棓㖏害 & 1 \\
\hline 勝脏痬 & 1 \\
\hline 外㑥性声忘症 & 1 \\
\hline 缺痤性通腰炎 & 1 \\
\hline & 85 \\
\hline
\end{tabular}




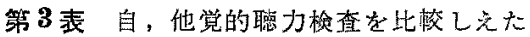
$5.1 \sim 62$ 年, 36 名, 68 耳の成縝

\begin{tabular}{|c|c|c|c|c|c|c|c|c|}
\hline & \begin{tabular}{|l|l|l}
125 \\
$c p s$ \\
\end{tabular} & 260 & 500 & 1000 & 2000 & 4000 & 8000 & 㖕 \\
\hline 差 & 56 & 65 & 66 & 65 & 59 & 57 & 49 & 417 \\
\hline$-15 d b$ & 0 & 0 & 1 & 4 & 0 & 0 & 0 & 1 \\
\hline-10 & 2 & 2 & 1 & 0 & 0 & 0 & 0 & 5 \\
\hline-5 & 2 & 2 & 4 & 5 & 3 & o & 0 & 19 \\
\hline 0 & 13 & 16 & 17 & 23 & 15 & 13 & 11 & 10 \\
\hline+5 & 12 & 13 & 14 & 15 & 14 & 14 & 14 & 96 \\
\hline+10 & 13 & 10 & 16 & 14 & 18 & 18 & 11 & 106 \\
\hline+15 & 10 & 12 & 9 & 6 & 6 & 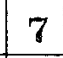 & 10 & 6 \\
\hline+20 & 1 & 3 & 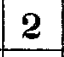 & 1 & 2 & 1 & 2 & 12 \\
\hline+25 & 2 & 0 & 1 & 1 & 1 & 0 & 1 & 6 \\
\hline+30 & 1 & 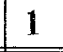 & 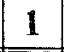 & 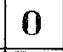 & 0 & 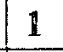 & 0 & 4 \\
\hline$\pm \mathbf{0} \mathrm{db}$ & $23 \%$ & 24.6 & 25.7 & 35.3 & 25.4 & 24.5 & 22,4 & 25.8 \\
\hline $\pm 5 \mathrm{db}$ & 48.2 & 47.6 & 53.0 & 66.1 & 54.2 & 52.6 & 51.0 & 53.2 \\
\hline $\pm 10 \mathrm{db}$ & 75.0 & 75.3 & 78.7 & 87.6 & 84.7 & 84.2 & 73.4 & 79.8 \\
\hline
\end{tabular}

て 79.8\%が自覚的聴力檢查の結果上一致する. 又 (一) のものは 8\%，(十) のものは92\%で，自覚的㦈力桧查 の結果より聴閾值が上昇しているが，平均愦差は $6.6 \mathrm{db}$ 以队率る。

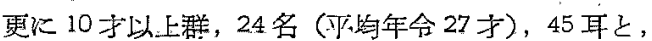

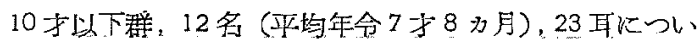
て信頼限界の比輍は（第 4,5表）の如く，前者に特ける

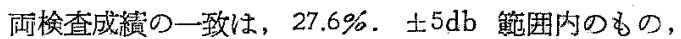
$58.0 \%$. $\pm 10 \mathrm{db}$ 以内のもの, $82.4 \%$ であり，後者にお

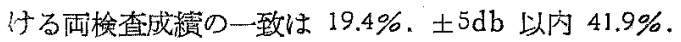
$\pm 10 \mathrm{db}$ 以内 $74.0 \%$ となり，10才以下韧の成續は 10 子

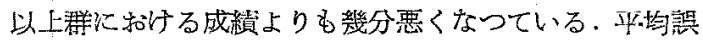
差は夫々 $3.8 \mathrm{db}$,及び $8 \mathrm{db}$ 以内である。

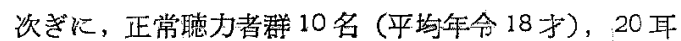
之，雉㯖者 26 名（平均年命 21 才），48 耳の信頼限界 の比較は，(第6.7 表) の如くで，前者に和子る P.G.S.R.

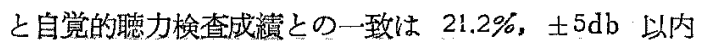
$42.5 \% ， \pm 10 \mathrm{db}$ 以内 $75.6 \%$ ：媵者における車成續の一

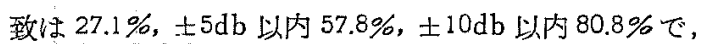

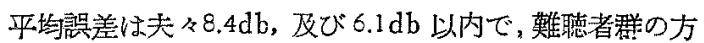

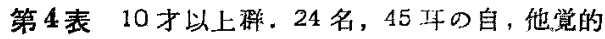

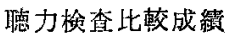

\begin{tabular}{|c|c|c|c|c|c|c|c|c|}
\hline & 125 & 260 & 500 & 2000 & 2 & $\rightarrow a$ & 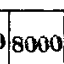 & A \\
\hline 部盖 & 41 & 45 & 44 & 4.3 & 41 & 40 & 37 & 29 \\
\hline$-15 \mathrm{db}$ & 0 & $\mathbf{U}$ & $\mathbf{U}$ & 0 & 0 & $\mathbf{U}$ & 0 & 0 \\
\hline-10 & 0 & 0 & 1 & 0 & 0 & 0 & 0 & 1 \\
\hline-5 & 2 & 2 & 2 & 0 & 3 & $\approx$ & 0 & 1 \\
\hline 0 & 12 & 13 & 13 & 16 & 8 & 10 & 10 & 8 \\
\hline+5 & 11 & 7 & 12 & 12 & 12 & 9 & 10 & \\
\hline+10 & 7 & 12 & 8 & 9 & 13 & 13 & 8 & \\
\hline+15 & 8 & 10 & 7 & 3 & 3 & 6 & 7 & 4 \\
\hline+20 & 1 & 1 & 1 & 0 & 8 & 0 & 2 & $n$ \\
\hline+25 & 0 & 0 & 0 & 0 & 0 & $\mathbf{U}$ & 0 & 0 \\
\hline+30 & 0 & 0 & 0 & 0 & 0 & 0 & 0 & 0 \\
\hline$\pm \mathbf{0} \mathrm{db}$ & 29.3 & 28.9 & 29.6 & 37.2 & 19.5 & 22.2 & 27.1 & \\
\hline $\pm 5 \mathrm{db}$ & 61.0 & 48.9 & 81.4 & 722 & 56.1 & 625 & 642 & 58. \\
\hline $\pm 10 \mathrm{db}$ & 78.2 & 75.6 & 81.8 & |03.0 & 87.8 & 85.0 & 75.7 & 82. \\
\hline
\end{tabular}

第5表 10 才以下群. 12 名，23㚎の自，他觉 的聴力检查比较成綡

\begin{tabular}{|c|c|c|c|c|c|c|c|c|}
\hline 用级 & 25 & $2 \ddot{0} 0$ & 500 & 1000 & 2000 & 4000 & 8000 & 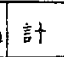 \\
\hline 差 & 15 & 20 & 22 & 22 & 18 & 17 & 12 & 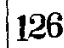 \\
\hline$-15 d b$ & 0 & 0 & 1 & 0 & 0 & 0 & 0 & 1 \\
\hline-10 & 2 & 2 & 0 & 0 & $\mathbf{0}$ & 0 & 0 & 4 \\
\hline-5 & 0 & 0 & 2 & 2 & 0 & 1 & 0 & 5 \\
\hline 0 & 1 & 3 & 4 & 7 & 7 & 3 & 1 & 26 \\
\hline+5 & 1 & 6 & 2 & 3 & 2 & 5 & 4 & 23 \\
\hline+10 & 6 & 4 & 8 & 5 & 5 & 5 & 3 & 36 \\
\hline+15 & 2 & 2 & 2 & 3 & 3 & 1 & 3 & 16 \\
\hline+20 & 0 & 2 & 1 & 1 & 0 & 1 & 0 & 5 \\
\hline+25 & 2 & 0 & 1 & 1 & 1 & 0 & 1 & 6 \\
\hline+30 & 1 & 1 & 1 & 0 & $\mathbf{0}$ & 1 & 0 & 4 \\
\hline $\pm 0 \mathrm{db}$ & $0.8 \%$ & 150 & 18.1 & 318 & 388 & 178 & 83 & 19.4 \\
\hline \pm 5 & 139 & 45,0 & 393 & 645 & 600 & 62.9 & 416 & 419 \\
\hline $\pm 10 \mathrm{db}$ & $66 \%$ & 760 & 72.7 & 77.3 & 777 & 823 & 66.8 & 740 \\
\hline
\end{tabular}


第 6 表 正常聴力者群。10 名, 20 㣉の自，他

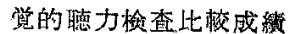

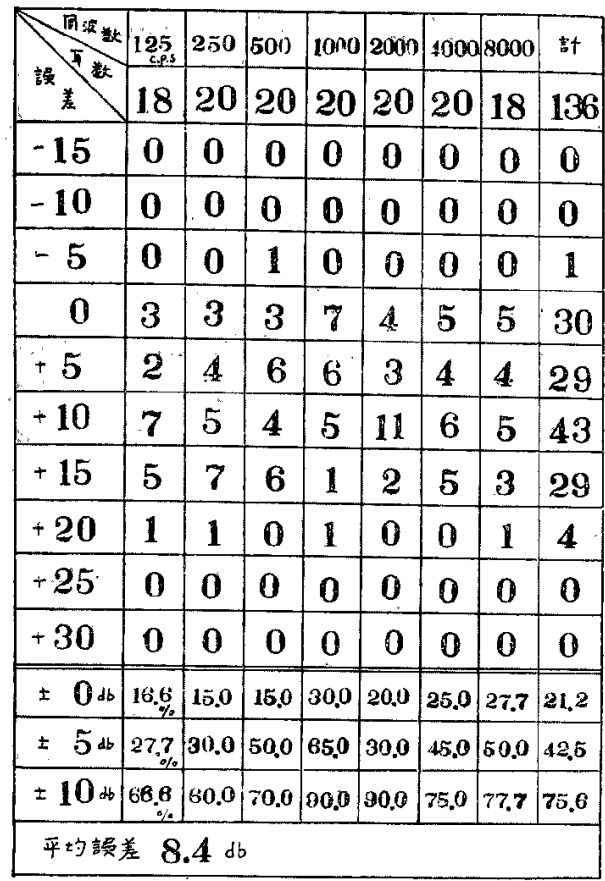

第 7 表 難聴者群。26名，48 正.自，他覚的 澺力㭲查比較成縜

\begin{tabular}{|c|c|c|c|c|c|c|c|c|}
\hline \multirow{2}{*}{ 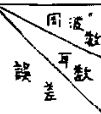 } & 125 & 250 & ธо00 & 1000 & 2000 & 1000 & 8000 & $\vec{s}_{i}$ \\
\hline & 38 & 45 & 46 & 45 & 39 & 37 & 31 & 281 \\
\hline$-15 d b$ & 0 & 0 & 1 & 0 & 0 & 0 & 0 & 1 \\
\hline-10 & 2 & 2 & 1 & 0 & 0 & 0 & 0 & 5 \\
\hline-5 & 2 & 2 & 3 & 5 & 3 & 3 & 0 & 18 \\
\hline 0 & 10 & 13 & 14 & 16 & 11 & 8 & 6 & 78 \\
\hline+5 & 10 & 9 & 8 & 9 & 11 & 10 & 10 & 67 \\
\hline+10 & 6 & 11 & 12 & 9 & 7 & 12 & 6 & 63 \\
\hline+15 & 5 & 5 & 3 & 5 & 4 & 2 & 7 & 31 \\
\hline+20 & 0 & 2 & 2 & 0 & 2 & 1 & 1 & 8 \\
\hline+25 & 2 & 0 & 1 & 1 & 1 & 0 & 1 & 6 \\
\hline+30 & 1 & 1 & 1 & 0 & 0 & 1 & 0 & 4 \\
\hline$\pm \mathbf{O} d b$ & 26.3 & 28.8 & 30.4 & 355 & 28.2 & 21.6 & 19,3 & 27.1 \\
\hline $\pm 5 \mathrm{db}$ & 57.8 & 533 & 54,3 & 68.7 & 64.2 & 56.8 & 51,7 & 57.8 \\
\hline $\pm 10 d s$ & $\begin{array}{r}78.9 \\
.\end{array}$ & 822 & 82.6 & 86,7 & 82.0 & 89.2 & 71.0 & 80.8 \\
\hline
\end{tabular}

第 8 表

\begin{tabular}{|c|c|c|c|c|c|}
\hline 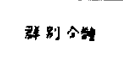 & 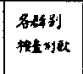 & 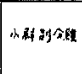 & 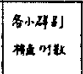 & 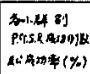 & 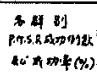 \\
\hline \multirow{2}{*}{$10 \pm: X \in Z F$} & \multirow{2}{*}{$\begin{array}{c}31 x \\
(4+928 \pi)\end{array}$} & 正学者 & $\begin{array}{c}10 x \\
(\text { tav22 } x)\end{array}$ & $\begin{array}{c}8 \pi \\
80,0 \%\end{array}$ & \multirow{2}{*}{$\begin{array}{l}25 \% \\
80.6 \%\end{array}$} \\
\hline & & 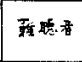 & $\begin{array}{c}21_{\lambda} \\
(\{=30 \pi)\end{array}$ & $\begin{array}{l}17 \% \\
80.9 \%\end{array}$ & \\
\hline \multirow{2}{*}{10 才曲下群 } & \multirow{2}{*}{$\mid \begin{array}{c}54 \\
(\bar{F} \cdots 47 \pi, 8)\end{array}$} & 正常看 & $\begin{array}{c}11 \\
(\neq 17472,8)\end{array}$ & $\begin{array}{c}21 \\
18.1 \% \\
\end{array}$ & \multirow{2}{*}{$\begin{array}{l}20 \\
37,0 \%\end{array}$} \\
\hline & & 䇝愊右 & $\begin{array}{c}43_{4} \\
(\sin , 4, \theta, g)\end{array}$ & $\begin{array}{l}18 x \\
41.8 \%\end{array}$ & \\
\hline 正常者群 & $21_{\alpha}$ & & & & $\begin{array}{l}10 \% \\
47.6 \%\end{array}$ \\
\hline 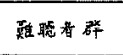 & $\begin{array}{c}64 \\
(\bar{x}+1) 13 \pi)\end{array}$ & & & & $\begin{array}{l}35 \kappa \\
546 \%\end{array}$ \\
\hline
\end{tabular}

が正常德力者群より信賽限界は良い結果となつている。

次ぎに以上の各群の P.G.S.R.-audiometry の成功率 を見ると(第 8 表) に示扣く，10才以上群，31人(平 均年令 28 -j）中の成功は 25 人にして，その成功率は $80.6 \%$ ，同群の正常聴力者 10 人中の成功恃 8 人 (80\%)， 難咕者 21 人中の成功は 17 人 (80.9\%) である.10才以

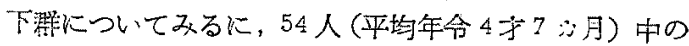
成功仙 20 人 (37.0\%) Kして，同群中の正常揌力者 11 人中の成功は 2 人 $(18.1 \%)$, 難㴔者 43 人（平均年令 4 闲 8 月）中の成功は 18 人 (41.8\%) である。立た，正

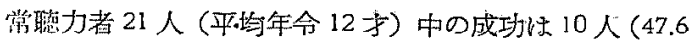
吕），蜼聴者群 64 人（平均年令 13 才）中の成功は 35 人 (54.6\%) である。な括本実験中，自敩的聴力榆查可能 の最年少者は 4 才 10 力月であり，P.G.S.R.-audiometry 可能の最年少者は 2 才 11 カ月である。西者共可能であ つた最年少者は前述の如く5才1カ月であつた。

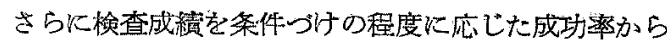
3群:に分けて見ると次ぎの上らになる(第9㾏).

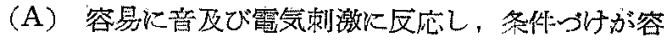
努な者. 45 人, $52.9 \%$ 。

(B) 音及び電気刺激に反応するが，租々の原因で条 作つがが困難か，ないしは不可能で正確な測定が出来難 い者. 25 人, $29.4 \%$.

(C) 音及び電気刺激に全く反応を示さない者。15人， $17.6 \%$ となる.

この成功率を各年令別にみると，第9表に示すよう に，2才以下ではO\%，2.1〜3.0才で初めて10\%となり，

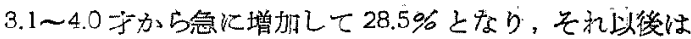
50\%，80\%，100\% と成功率憎大するが，こ永性必ず

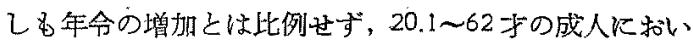
ても71.4\%にとづまっている。 
第 9 表 全症例 85 例の年令别成功度别成䌙

\begin{tabular}{|c|c|c|c|c|c|}
\hline 年 & 例数 & $A$ & $B$ & $c$ & 成功辛 \\
\hline $0.7 \sim 10^{\text {年 }}$ & 5 & 0 & 0 & 5 & $\mathbf{0} \%$ \\
\hline $1.1 \sim 2.0$ & 6 & 0 & 1 & 5 & $0 \%$ \\
\hline $2.1 \sim 3.0$ & 10 & 1 & 6 & 3 & $10 \%$ \\
\hline $3.1 \sim 4.0$ & 7 & 2 & 3 & 2 & 28.5 \\
\hline $4.1 \sim 5.0$ & 4 & 2 & 2 & 0 & $50 \%$ \\
\hline $5.1 \sim 6.0$ & 8 & 4 & 4 & 0 & $50 \%$ \\
\hline $6.1 \sim 7.0$ & $\dot{2}$ & 2 & 0 & 0 & $100_{\%}$ \\
\hline $7.1 \sim 8.0$ & 5 & 4 & 1 & 0 & $80 \%$ \\
\hline $8.1 \sim 9.0$ & 4 & 2 & 2 & $\mathbf{0}$ & 50 \\
\hline $9.1 \sim 10.0$ & 3 & 3 & $\mathbf{0}$ & 0 & 100. \\
\hline $10.1 \sim 15.0$ & 3 & 3 & 0 & 0 & $100_{\%}$ \\
\hline $15.1 \sim 200$ & 7 & 7 & 0 & 0 & 100 \\
\hline $20.1 \sim 62.0$ & 21 & 15 & 6 & 0 & 71,4 \\
\hline 計 & 85 & 45 & 25 & 15 & \\
\hline 成功率 $(\%)$ & & 529. & $294 \%$ & $17.6_{\%}$ & \\
\hline
\end{tabular}

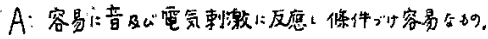

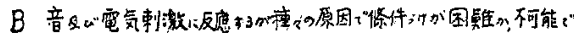

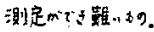

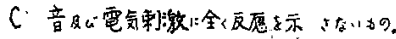

\section{V. 総括並びに考按}

被検者の皮膚の 2 刃所不分極電㥛をつけ，これを疑 敏な電流計につないだ後，急に被检者に大きな音を聞か せたり，または針をさして痛みをあたえるなど，外部か らの刺激をあたえるか，あるいは暗算させるとか，また は被檢者みずからが與奮するよらな時に，一時的に電流 变倾が見られる。これが P.G.S.R. の原理であるが， P.G.S.R. の歷実は, Vigouroux, Féré Tarchanoff, Veraguth，の頃から始まるとされている1)。

この発生機転は，間脳の視床下部 (hypothalmus) p 大脳の運動領 (pre-motor cortex $=$ Brodmann's area-6)

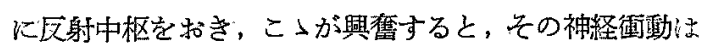
春随交感神経節を通り，交感神経の節後線維によつて遠 心路を形成し，反応器官である汗腺に伝えられる自律神 経反射であるとされている。これによつて汗腺細胞が期 鹰苍起こすとそこに活動電流が起きるし，圣，汗腺の細 胞形質膜の電気的透過性（分極）の一時的減少が見られ る.従つてこれらの变化を見る方法として，皮虞に電流

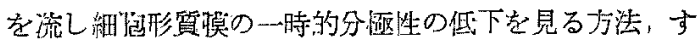

なわち，Féré 現㲻は，通電法と言われて一般的炕今日 まで行われてきた方法である・これに反して，電流を通

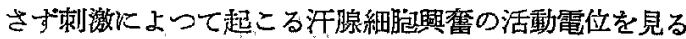
方法，すなわち，Tarchanoff 現象は，電位法といわれ てる，原理的には峏者恃異つているよらであるが，汗腺 の鲖奮を見よらとすることにはかわりはないようであ る.こ水らの現乘は，情緒的体験を值接測定できる方法 として, 心理学者, 双は生理学者には利用されてきたの であるが，最近これらの現象の本体に関する研究が進む につれて，これは精神作用と直接関保ある現象ではな 々，大脳を除去しても現われる現象であるとされてい る.藤森 2) 3) 4), 渐美 1) 等の研究に上れば, これらの現 像は種々の条件，すなおち，身体部位差，皮虞温，発汗 状態, 年令, 温度, 湿度, 電極の良否, 测定装置等によ りその現われ方が違つてくると言われている．近年医学 の進歩と共にこの現象を臨床医学に応用せんとする活動 が盛んになり，殊に耳鼻科領域に打いてもこ机を聴力測 定の具に供しょうとする考え方が 盛んになるてきた。 1947 年 Michels \& Randt ${ }^{\text {) }}$ が鼡波記録器を用いて， 条件づけを行かず音だけに上り，主として軍人の詐病の 発見のため用いたのがこの分晒えの応用のきさしであ る. P.G.S.R. 施行上一番因難な問題认順応見象（adaptation）である。第3図に見られる通り，音刺激，ま たは電気刺激単独では, adaptationが早く特こることが 分る. しかるにこれに Pavlov の条件区射を加克て条 件づけを行うと，adaptationは起り難いことが分る.

\section{第 3 図}

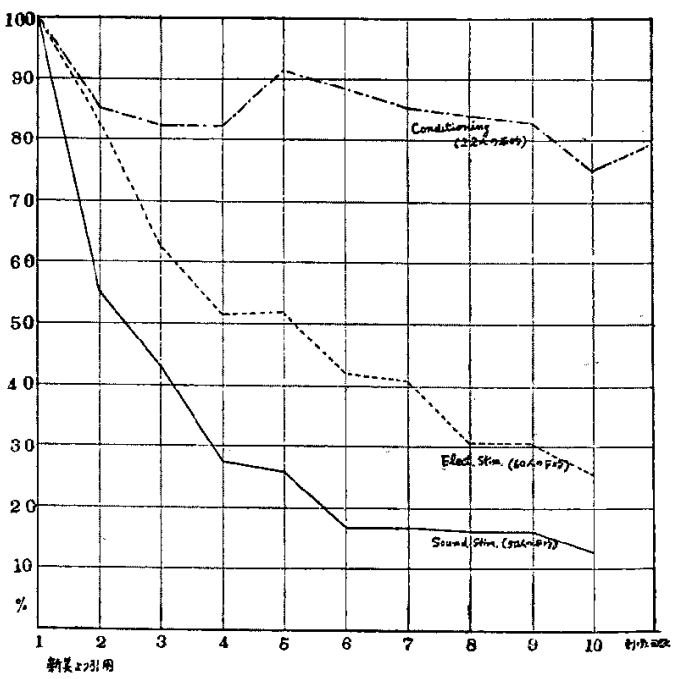


P.G.S.R.・に条件反射を她用して研究したのは，Ishrondsky だと言秃てている ${ }^{6)}$ ここれらの研究を基として今 日の P.G.S.R.-audiometry の基礎を゙築き上げた最初の ものは, Bordley \& Hardyi) (1949) である. その後 欧米に括いては P.G.S.R.-audiometry に対する数多く の搠判や研究の論文が発表された

本邦に推、て子森本，志井田 ${ }^{26)}$ を初め数種の研究が 発表されている゙7) 38) 39) 40) 41).

私はこれらの研究を参考にし，P.G.S.R. 装置につい ても種々，改良を加光，一応の成果を得たので，従来の 研究者の成績と比較検钓したい。

P.G.S.R. 装置について:-

前述の上うに P.G.S.R. を測定する方法としては，通 電法，拉よび電位法の2つがあるわけであるが，いずれ にしても两電福間の皮崛の impedance を確実にとらえ らる高感度の湘定器がます必要である. Bordley 以悲一 般的に便用さ礼ている，Wheatstone-bridge 回路，補 償結合回路は，P.G.S.R. を左右する上記の条件のほか K, 便用電圧や電流值が加かり，零点調整のための手数 が更に加わる．蓄電気式回路では，波形の查みが著しい などの点も西る、私は，操作し易いという点から考克 て，電位法による湘定装置を作つた。この一般的特微 は，(1) 負瞶還增幅力式であるため，增幅器で生ずる歪 みを少なくし，先の增幅度は，電価や電圧，只の他真空 管の插し替えに詨してる無関係にすることができるばか りでなく，位相差，周波数歪みを著しく減少することが できること.（2）外部電圧による障害を除くため，差動 增幅器を用いたこと. (3) 90〜110V 委での電圧变仩沉 対して装置恃安定であること。（4）安定化電源は差動 率, $1 \times 10^{-0}$ であること.及び（5）時定数は 1.5 秒とし たことなぞである。

藤森 2)は，時定数は最低 1.5 秒，できるだけ，3秒程 度が良い之言つているが，私の研究では，皮膚抵抗の長 い变化を見るのではなく，反射の有無を見ることっ，刘 象が主に子供である点などを考光て，時定数が小さい ちが反射の観察に便利であると考えたしたいである。

Stewart ${ }^{18)}$ は従来の bridge 回路の不備を除いた差動 洄路による新しい装置を作成し記録の単純化をはから た. Kirschner ${ }^{8)}$ は P.G.S.R. は複雑な要素が入るの で，1つの switch で行点るよらな簡易性が望をしいこ とをのへてている臨床的には通電法は前述したよらな稙 ネの欠点を含むものとして，電位法に上るもの১ほうが 便利であると思われるので, 本研究に批てては,この電
位法を採用した。

測定条件について:-

縏条件刺游には何が適当がとい5問題に関して，Tato 20)は，光刺激による P.G.S.R.-audiometryを行つた成 續から，失敗は 29 人中 5 人であり，充分に実用的であ るとしている。光刺激は被検者化不快感を与えない点便

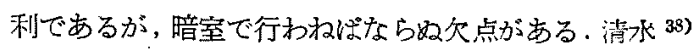
は，絵及び光刺激は，反射が小さく adaptation.も早く て条件つけが困難であると言つている。この上らな点か

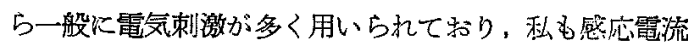
及び蓄電器放電電流を使つて見たが，感応電流法上腕及 び下眼につけた場合でも不快感よりも痛覚が強く，から 短絡などによる危除をさけることができない。これに反 して蓄電器放電電旅は全く痛觉がなく，不安期待感の堌 強には啇して物り，佶险むないのでこれる使用したので ある。また電極の裝着部位については，年長者の埸合 は，指尖に電極をつけたほらが不安感は同一ボルトでむ 增大するから都合がよい，子供は大人に比し，強い艦気 刺激にたえらるが，P.G.S.R.。の反射量及び被检者の状 態を見て，最初は弱く次第に强くして，通常 $10 \sim 30 \mathrm{~V}$ の籁团で電圧を変化させなががら条件づけを行つたほう が反射の持続には刘果がありた. P.G.S.R. 電㥛は乳幼 児では足蹠につけたが; 手掌につける埸合でも, きょ胞 と反対側につければ子供の不渾感を除去しうる。刺激音 は正常德力者では，10c0cps 40 50dbを与文公が，難

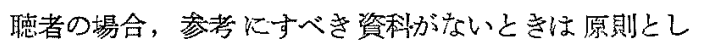
て, 500乞ps 70〜90db t与六た. Merister \& Doerfler ${ }^{15)}$ の研究によれば，同一サ!クルに持ける $30 \mathrm{db}$ 群之， $30 \mathrm{db}, 50 \mathrm{db}, 70 \mathrm{db}$ の各種の変化群との間には，消去反 応数に著しい相違はみられなかつたと言つているので, 条件刺激音の強さの変化は意味がない, 操作自体を複 雑にするばかりと思われる。

また刺激音の持続時間については, P.G.S.R.は1〜2 秒の潜伏期をえて，3秒程で項点に達するので剌激音の 持続時間があすり短いと，被検者に充分音を認識させる ことができず，また次に与充る電気刺激による反射波形 と重なる埸合もあるから少くとも4〜5秒間は聞かせる 必要がある。この钼点から，私は刺激音の持続時間と して5〜8 秒を採用した。をた電気刺激は私は，刺激音 の0.5〜1 秒後比与克ているが, Goldstein, Ludwig \&

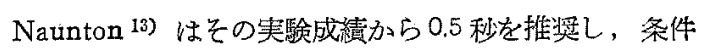
つけ難いものに対しては 5 秒後に与去ている。宗たBordleyi) は1.5秒後に, Goodhill, Rehman \& Brock- 
man 21) 4〜5 秒後に与えているように，この時間的間嵒 については，各䀦究者に上り一定していない，一般に多 くの研究者柱，早期（1２秒後）に与克ているが，それ ぞれの成績には著しい相違はみられない，剌激音の間隔 はできるたけ哣縮して検查が䅱時間に終るのが望ましい

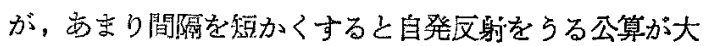
となり, adaptation も早くおこるようになり, 基線そ のものむ落らつかないから，検查が容易なものには，短 い間隔で行ない，一般には20秒〜1 分間を任意に変化 させた。な叔通電法を优用している人々は，装置そのる の>性質から50〜60秒間䧣を主張している。

前にものべたように，P.G.S.R.は䏇覚刺激のみなら ず乞の他の異つた刺澈からも溗発することができるの で, 聴覚刺激特有な反射ではない。したがつてこの特 殊性の不足から，本检查注無条件刺激に上つて条作づけ

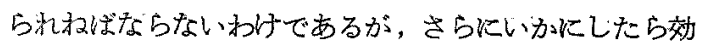
果的に条件つけ後の反射の掊続を保らうるかという問題 にも関連して，案件づけの方法に2つのいき方があるよ らに思小れる。すなわら (1) 音刺激毎に電気刺激を加 えて条件一引ける方法.すなわち，全体的增强法と，(2)

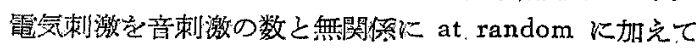
条件つける方法、すなわら，部位的增強法とである。前 者は, Bordley \& Hardy $)^{7}$, 清水 ${ }^{88)}$, 金谷 ${ }^{39)}$ 等に上 つて広々一般的行われてきた方法であり，後者は， Merister ${ }^{15)}$, Doerfler ${ }^{16)}$, Goldstein ${ }^{34)}$, Stewart 19),

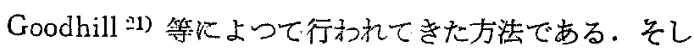

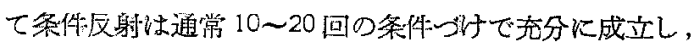
通尝 30 分は持続すると, Bordley ${ }^{28}$ ) は述へてて特り, 清

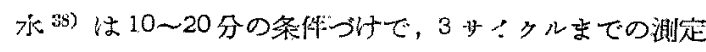

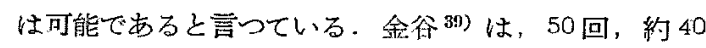
分間の条件づけを行なつているようであるが, Merister， Clay \& Doerfler ${ }^{15)}$ の研究に上れ涹，100\% 增強法と， 40\% 增强法の間には，条件づけ後の反射数の相違があ り，40\% 增強法が良いことをのべている. 契際には(1) の方浩のみを取つている人は少なく，最初は全体的增強 法に上り，反射量を観察しながら途中で 4 5 回の部分 的增強法を加之た行き方が検查には便利なので，悡はこ の方法を採用した。検查の所雬時間は悡の成續では20 分〜1 洔問半にわたつたが，子供の場合は彼等が緊張し ていられる時間は，15〜20分程度であるので，途中数 回の遊びを入れたりしても，1時間を限度とし，検查が 終了しない者には翌日をた行らようにした。

検查は大人に対しては，下降法と上算法の雨者を比鞈
してみたが，反射数の㨋しい相違は見られなかつだ.小 西，福岛，傾川 ${ }^{40)}$ は, adaptation の考慮から下降法を 否定しているが，下降法の方が反射波形の観察に便利た し、間違いが少ない上うに思和れる。原則として，私。 は，10db step の下降法を用いたが，特にこれにこだわ。 らず，闒値附近と思われる所までできるだけ早く下げ， 閾值附近では $5 \mathrm{db}$ step で観察した，この方法では检査 時間の短縮と，adaptationを十分にさけ得るし，125cps ～8000eps むでの樎查音の测定が十分可能であつた。 P.G.S.R. К上る波形そのものは，脳波ほどの複雑性は ないから簡単であるが，音だけに特有な波形はない，梁

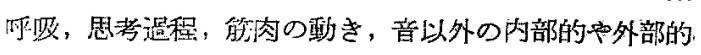
刺激でも同じ上らな波形がえられる。従つて波形そのも

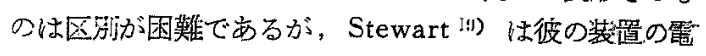

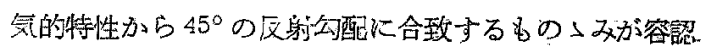
できる反射であるといつているまな彼は自発反射るう る公算は20\%であるが，不用意に，音を゙かせないで 電気刺激を与えると，これらの自発原射は增すと言つて いる、音に沜する反射は100\% あるとは限らない，従つ て自発反射之，音刺激による反射とが，同時に重ならて

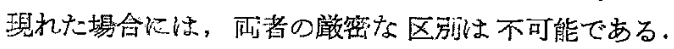
Doerfler ${ }^{16)}$ は，潜伏期，波形の最小振幅，公配から区 别しらると帚つているが, Goldstein, Ludwig \& Naunton' ${ }^{13)}$ 及び Withrow 39 は音刺激後 1〜3秒迄起ら ないむの愔反射とは麗められないとして除外している が，Goodhill 21 等は，潜伏期肪 4〜5 杪のものもあつ たと言つている．寒際にそのように潜伏期が大きいるの では，私の絰験でも条件づけが想だ困難であり先敗に終 つている，波形の分析は，被㛟者，及び算息によつて幾 分の相違はあるか゚，蛽れつげそれ程困難ではない。

検查成績について:-

P.G.S.R.-audiometry は，この上5K主雏的解訳の

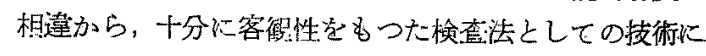

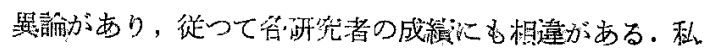
は検㚗成綂を各群に分類し，それぞれについて各研究者

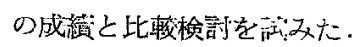

10 于以上群について:- 31 人（平均年令 28 才）中条 件つけに成功したもの25人，失敗6人で，その成功率 は80.6\%で放つた（第8表参炤）この成功例のうちて

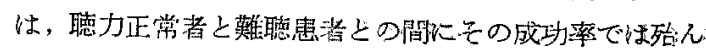
ぞ差がなく，80.0\%〜80.9\% であつた.しかし失敗は 20\% オ以上の省が全部で，その内訳は労働者で手掌成呞の非 常㴡い者2名, 外傷性 Aphasie 1名, 身体的心は全 
〈異常なく数十回の条件づけにも拘らずな揲条件区射が

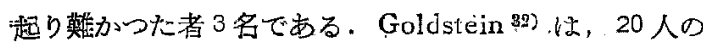
大人の非器質性難聴の 条件づけの成功率は $50 \%$ である と言つているが，彼の测定法置や污法が私之同一采件で はないので比較し萪いが，Bordley ${ }^{28)}$ は，成人 20 人中 の失敗は $2 \%$ 以内であったという。乙かし成人には，生 活条件江伴万個体差やその他の不明の原因に上つて条件 るけ難いるのが多い上らに思われる。

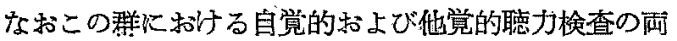
者を比較し得た成预标 24 名（平均年令 27 才） 45 耳で， (第 4表参照)，その誤差筑围は $-10 \mathrm{db} \sim+20 \mathrm{db}$ にわ たつて分布したが，125cps〜8000 cps の7 種類の平均值 は, $58.0 \% か ゙ ＼pm 5 \mathrm{db}$ の籍囲内に, $82.4 \%$ は $\pm 10 \mathrm{db} の$ 䑨囲内にあり, 平均誤差は 3.8db 以内であつた。 Maspetiol 1) 蛙成人では 10 20db 高いと言らが; Bordley 28) は $5 \mathrm{db}$ 以内であるとい〉, Doerfler ${ }^{16)}$ 等も $\pm 5 \mathrm{db}$ 以内であり平均 $3.5 \mathrm{db}$ であると言つている. 大人に和 ける成續は，他の研究者の報告でも良好で，これには翼 論がない上らである. P.G.S.E.-audiometry の大人K

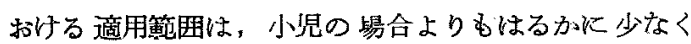

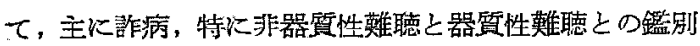
にあると思われるが，Glorig 42) は，P.G.S.R. b胹波 小器質性, 機能性の区別は可能であるが，機能的なるの を更汇，仨病之精神作用による制圧によるるのとに区別 できなければ結果的纫は鑑別の正確な方法とはなりえな いという。しかし詐病についての従来までの検查法のう ち delayed speech test を除いた他の方洗，守衣わら (1) 最小可聴閧值のくりか光し 検查. (2) Lombard test. (3) Stenger test などょりる P.G.S.R. 法は実 用的価值があるように思放机る。

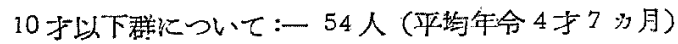
中, 条件つけに成功したものは20人, 失敗は 34 人で, その成功率は 37.0\%であつた。これは本検查が 4 才以下 の年令層に重点を置いたつめ，この年令管に被検者が多 がつたので成功率は比較的低かつた。 P.G.S.R.-audiometry の困薙性や失敗の問題は，殆えどがこの年令層 に集中されている。な和正常聴力をすつた子供の standard pure tone audiometry. 化の成亚は 4 于10 カ月が最年少者であつたが， Irwin \& Shreve ${ }^{43)}$ は 4 〜の才迄の子供江訓綡汇よつて可能であるという．しか し信賴しらる standard pure tone audiometry は一 般的には 5 才以上でなければ困難であらう。

P.G.S.R.-audiometry は年令的制約をらけるか否か

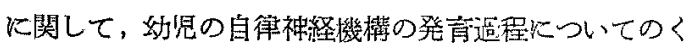
わしい交献がないのでよくかからないが，猪児は一般に 自律神経民射の発青が抢そく，その完全な機能は4５

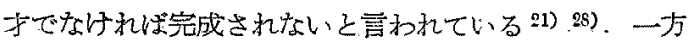
Marcus 43) は条件反射システムで信頼で热る程度に行 おれるの性2〜2方半位からであるといら. Goldstein, Polito-Castro \& Daniels ${ }^{25)}$ は32人 (7子6引月〜12 才 8 月, 正均年令 9 才 10 力) の正常な聴力者及び 正常な知能者の条件づけの研究から，この年令圈に打い

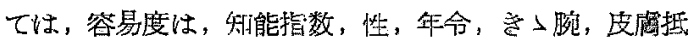
抗及びその变動性，潜伏期，明白な反忘動作などと無関 侯であると言い，18 人は容易で 14 人は困灌であり，正 常览童は Aphasie の児童ににた反応を示す上うに思わ れると言つている.悡の研究では，この年令層の例数が 少なからたので比輘し難いが，年令が若くなるにつれ検 查の失敗例は增大した。殊に 4 才以下の幼垐ではこの傾 向は大きからた。すなわら成功率は 2.1 才 3.0 才で 10 \%，3.1 才〜4.0于で $28.5 \%$ にすぎなかつた。金谷 ${ }^{39}$ は 检查不安えの服消が成功をるたらす場合が多いことをの ベており，また Hardy \& Pauls ${ }^{1 n)}$ 等は検查前の準储 中のくつろぎの必要性を强調するが，検查の測定条件及 びこれらの身体的条件が十分に満たされた場合です，4 才以下では反射が起らない場合が多かつた (71.5\%)，2 才台 10 人のらち，成功は 2 才 11 \%月のI例 (10.0\%) で，他の9人は何等かの原因で失敗した．なた 1 年圭满 の 5 人は P.G.S.R. が全く見られれからた（第9表参 照). Bordley 28).は，1.8年では検查はさほど困嫨では ないが，それ以下では非常に失敗が 多からたと述へ， Barr "4) は，2.5 年以下で恃成功率は 50\%に长達しなか つたと言つている. Statten \& Wishart ${ }^{33)}$ は，2才 以下の成的は 42 人中，おずが 2 例であつたという。 Maspetiol, Gougerot \& Korin ${ }^{9)}$ は, 4 才以下では困 難であると述べているが，韭の成績からすれば，2予以 下では成功せず，3泤以下では稀に成功し，4 才になつ て約 30\% の成功等になるといつてよいと思われる。し かて 4 才以上になつても $100 \%$ の成功率になるとはい光 ない，清水 ${ }^{38}$ は，1.1 年の检查を，金谷 ${ }^{99}$ は，1.9年 の検査の成功をのべているが，厸の成績からみれば，こ れらは例外的なものに入れるべきではないだるらかと思

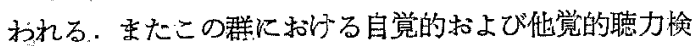
查の而者比較し光た成續は，12名 (23耳，平均年令 7 才 8 カ月）にして，その最年少者は 5 丹 1 月列ある が，両者による誤差範围は， $-15 \mathrm{db} 〜+30 \mathrm{db}$ にわたつ 


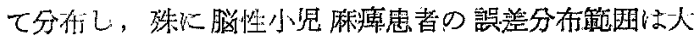
であつたが，検查した 全周波数音の 平䏛值は $41.9 \%$ が $\pm 5 \mathrm{db}$ 以内にあり，74.0\%は $\pm 10 \mathrm{db}$ 以内であつた。 そして平均誤差は $8 \mathrm{db}$ 以内であった（第 5 表参照).こ の結果は10才以上稓よりや〉悪い結果を示している(前 者：後者 $=41.9 \%: 58.0 \% ， 74.0 \%: 82.4 \%)$. 年少者に おける比較成續性検查方法によつても異つてくると思わ れるが, Bordley \& Hardy ${ }^{28)}$ は，39人（4オ〜18才） 平均 8 才061〜73\%は $5 \mathrm{db}$ 以下であると言つている. Faure ${ }^{28)}$ は，真の闖值は P.G.S.R. 法に上り得た閔 值より2寻〜4才では $15 \mathrm{db}$ 下であり，4才〜7才では 10db 下である之言っている. Maspetiol, Gougerot \& Korin 92は，4チ〜8甬では 15〜20db の相違があると い5. Portmann. M. \& Portmann. C. ${ }^{27)}$ 林，4才〜7 すでは 10db 下であると言つている，自覚的聴力検査の 結果が年少者では殊に，真の閔値と言い難いが， $\pm 10 \mathrm{db}$ の訐容籍囲を認めるなら私の成績は此較的満足できる結 果であうう.

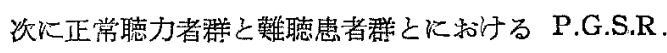
の成功率と比較考察してみよう。

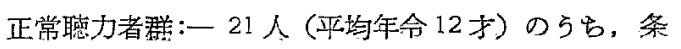
作づけに成功したものは10人，失敗は11人で，その成 功率は $47.6 \%$ であつた (第 8 表参照)，また同群に和け る自営的括上び他覚的聴力検查比较成續は，10人 20 耳 (平均年令 18 才), で両者の誤差籍国は $-5 \mathrm{db} \sim+20 \mathrm{db}$ にわたつて分布し，42.5\%は 土5db 以内であり，75.6\% は $\pm 10 \mathrm{db}$ 以内であつた。 そして平均誤差は $8.4 \mathrm{db}$ 以 内であった。これに反して，

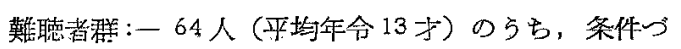
けに成功したものは 35 人，失敗は 29 人で，その成功率 は 54.6\%であつた（第8表参照）、すなおち, P.G.S.R.

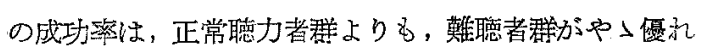

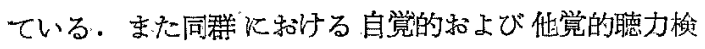
查を比較しえた 26 人 48 耳（平均年令 21 禾）の成結は $-15 \mathrm{db} \sim+30 \mathrm{db}$ にわたつて分有し， $57.8 \%$ は $\pm 5 \mathrm{db}$ 以内であり， $80.8 \%$ は $\pm 10 \mathrm{db}$ 以内であつだ. 平均䛊 差は $6.1 \mathrm{db}$ 以内であのた。

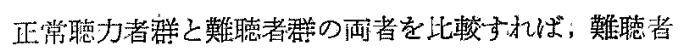
群の力が条件づけ易く，かつまた自覚的特よび他賞的聴 力検查比輘成績も良いことが分る。文の理由は，現在明 らかでなないか゚, 恐らく難㯖者にとつて, 音が聞克る亡 いらことが正常聴力者には想像もできない汪どの刺激を 彼等に与竞る結果ではかららか。この成續は金谷、照》。
Goldstein, Polito-Castro \& Daniels:5) らの報告たす 認められる.10才以上群では，正常聴力者，難聴者共 にその成功率は約 $80.0 \%$ という同じような結罙を得た が，10才以下群では，正常聴力者 11 人中の成功は 2 人 (18.1\%)であり，澌㯖者 43 人中の成功は 18 人 ( $41.8 \%)$ でやはり難聴者群の成功率が正常聴力者䖽上りるよい これは難聴动児では殊に音に対して注意を引き易いため ではないだらかと推察される。な和全症例 85 名 (5.1 オ〜62才）の5吕，その成功率は 52.9\% (45名) であ る.これら成功例のうち，自覚的乱よび他覚的聴力検查 を比較しえた 36 人， 68 耳の成續は，53.2\%が $\pm 5 \mathrm{db}$ 以内であり，79.8\%が $\pm 10 \mathrm{db}$ 以内で, 平均愦差は 6.6 $\mathrm{db}$ であつた（第 3 表参照）. 失敗例 40 名の5ち25 名 (29.4\%) 恃音牤上び電気刺激炕対Lて P.G.S.R. 性起つ たが，䡒々の原因で条作づけができ難かつたか不可能で あつたものであり，全く反応を示さないるのが 17.6\%で あつた（第9表参照).これからみて，P.G.S.R.audiometry は，さらに研究する余地が殆されてばいが， 現在のところではすず臨床的には洒值があると思われ る. play audiometry では条件ら゙けができなければ音 への反応の有無の客観的基潐を全く持ちえない. Hardy

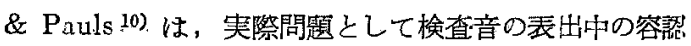
可能な時間内に発生する波形は，ぞれも反応として重大 である・いくつかの例では検流計の休止さえも重大な区 応であるかる知礼ない之言つている. Goldstein ${ }^{14)}$ 快 成屬抵抗の变化からと同㥞に，P.G.S.R. が出なくても 音を聞いて，汒いたり，困惑したりする児童の動作から 多くの知識をうるから，他の検查の資程炕附加すべき貝 重な資科を提供すると言つている。従つて第9表のA， B の合計 $82.3 \%$ は臨床的には価值があり，放裹すべき 成續ではないと思和れる。

P.G.S.R.-audiometry は，1才来满の乳照の検查环 は、末本だ十分実用的ではない。これら乳枈に対しては、 Froeschels 45) 46) の直接音挿入法, Wedenberg 47) の

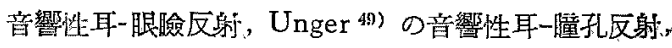
Wishart ${ }^{48)}$ ）笛その他檑々の道具からの，発盲過程に 打ける正常動作反応の知識から難恥の有無を見る方法な ぞが役立つと思われる．P.G.S.R. 法と前えで現在研究 されている方法に，篮波を利用する方法がある14) 34（42)

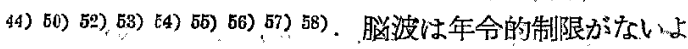
万思えるが，P.G.S.R, 以上の複雑さと，熟練要要与 る点などからな挘研究の余地があり，今後の発展が期待 される。 
standard pure tone audiometry のできない年少奻 児に対しては，さらに play audiometry がある24)3931) 609 61) 62) 63; 64) 65) 66) 67)。従つてこ礼らの低い年令層に 対する P.G.S.R.-audiometry の信頼限界に関する研究 では, 主に脳波法特よび play audiometry との比輁が あげられる. Statten \& Wishart ${ }^{33)}$ は，101 人の幼児 の P.G.S.R. 法による成功は50\%であり, play audio。 metry では63\%が成功したとい〉，Barr 24) は，7才 以下の音に反応ある幼児 115 名の P.G.S.R. 法による成 功怯 95 名, $83 \%$, play audiometry 472 名, 63\%が 可能であり, play audiometry と P.G.S.R. 法によつ て得られた闒値は測定しえたものでは実際的に一致した と言つている. Schulz ${ }^{35)}$ は，7才以下 29 名の，光を無 条件剌激として用いた P.G.S.R. 法上, play audiometry との比䔻において、75\%は $5 \mathrm{db}$ またはそれ以下ですつ たと言つている。金谷 ${ }^{99)}$ は23名中 P.G.S.R. 法による 成功は 16 名, 70\%，play audiometryによるもの13名， $57 \%$ ，でこの中 67\%は $55 \mathrm{db}$ 以内であつたと言つてい る. Withrow \& Goldstein ${ }^{34)}$ は, 睬波法と P.G.S.R. 法との比較で両者の反応の愦差は $\pm 10 \mathrm{db}$ 以内であつた と言つている・さらに眇波による疑反応は，P.G.S.R. より多く，従つて P.G.S.R. 法より信賴性が少ない. ᄂ か乙媨波は年令的制限はない上うに思らと言つている。 これから見れば，現在のところ P.G.S.R. 法は play audiometry や脳波法よりむすぐれているように思われ る.

P.G.S.R.audiometry の実用性については，他の test でるそうであるが，ぞんな精功な P.G.S.R. 装置をるつ てしてい聴力検查ができない場合があるように，これだ けて満足すべきるのではない. 従つて P.G.S.R. 法は他 覚的聴力検查としての最後の決定的な解答ではなく，佗 觉的㯖力検查の附扣的存在であると考点るべきである が，乙かし実用価值のある検查法であることは間違いな い. さらに play audiometry, speech audiometry どと併用して行えぱ，さらに臨床的猃断に確実性を增す 実用的検查法であると考えられる。

\section{VI. 結 語}

P.G.S.R.audiometry を電位法により，7わ月〜 62 j にわたる 85 名に施行し，次の成績を得た。

(1) 自覚的打よび他觉的聴力検查の同者を施行しえ た，5 方 1 カ月〜62 才をでの 36 名， 68 耳の信頼限界を 比較して，誤差籍囲を $\pm 5 \mathrm{db}$ にとれば，53.2\%が一致 し，土10db にと机ば，79.8\%が一致した。
(2) P.G.S:R.audiometry は standard pure tone

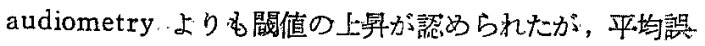
差は, $6.6 \mathrm{db}$ 以内であつた.

（3）全症例を 3 群炕分けて䘽察した結果は次の通りに

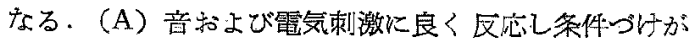
容易なるの，45名，52.9\%．(B) 音および電気刺激に反 応するが，䅇々の原因で条体つけが困難か不可能で，正 確な測定ができ難いもの．25名，29.4\%。（C) 音乱よ び電気刺激仁全く反応しないわの15名，17.6\%。

(4) 3卞以下では, P.G.S.R.-audiometry の困難性が 堌し，稙々の原因で失敗に終ることが多い，湘定し得心 最年少者は，2才 11 カ月であつた. P.G.S.R.-audiometry は，他覚的聴力检查の補助的存在として実用価值が あり，本法単独での成功率は低からたか，他の検查法と の㑜用でさらに臨床的実用性が增するのと思われる。

(5) P.G.S.R.-audiometry の成功率は10 浦以上の者 では80.6\%，10才以下の者では37.0\%であり，末た正 常璃力者上りも難聴者に成功率が多く，殊に10于以下 の難聴者では $41.8 \%$ の成功率を示した。

$$
\text { 文献 }
$$

1) 新美, 相場：GSR 研究の手引，山越整作所，炤32。

2) 藤䅨：医学エレクトロニクス，南山堂，p.318 $327,1954.3)$ 藤森: 臨床電気生理学, 医学書院, p. 85 96, 1955 4) 藤森：脳之神経, 5 卷, 5 号, p. 259 283, 1.953. 5) Michels, M.W. and Randt, C.T.: Galvanic skin response in the differential diagnosis of deafness. Arch. of Otolaryng. 45: p. $302 \sim 311,1947,6$ ) 古武，新浜：条件反応，共立 出版株式会社, 1956.7 7) Bordley, J.E. and Hardy, W.K.: A study in objective audiometry with the use of a psychogalvanometric response. Annals of Oto. Rhino. \& Laryng., 58: 3, p. $751 \sim 750$, Sept., 1949. 8) Kirchner, J.A. and Haggart, H.H.: A skin resistance audiometer. Arch. of Otolaryng. 52: 6, p. 952 956, Dec., 1950. 9) Maspetiol, Gougerot, L. et Korine:: Objective audiometry based on the psychogalvanic reflex. Presentation of an apparatus for the measurement of GSR techniqueof examination. Excerpt. Med. Sec. 11. 5: p. 225, 1592. 10) Hardy, W.G. and Pauls, M.: The test situation in PGSR audiometry. Journal of S. \& H. Disorders. 17: 1, 13 24, March. 1952. 11) Faure, J. Portmann, M. and Portmann, C.: The 
possibilities and limitation of psychogalvanometry in aúdiology. Excerpt. Med. Sec 11, 6, p. 153, 1953. i12) Barr, B.: Psychogenic deafness and objective audiometry. Excerpt. Med. Sec I1, 6, p. 310, 1953. 13) Goldstein, R., Ludwig, H. and Naunton, R.F.: Difficulty in conditioning galvanic skin responses.: Its possible significance in clinical audiometry. Acta Oto-Laryng., 44: 1, p. 67〜77, 1954.

Goldstein, R.: Detection and assessment of auditory disorders in children less than three years old.: A critical review. The Volta Review. Reprint No.661. 15) Merister, Clay, L. and Doefler, L.G.: The conditioned GSR under two modes of reinforcement. Journal of S. \& H. Disorders, 19 : I, p. $350 \sim 359,1954$. 16) Doerfer, L.G. Mc Clure, Catherine, J.: The measurement of hearing loss in adults by GSR. Journal of S. \& H. Disorders, 19: 1, p. 184 189, 1954. 17) Dupon-Terson. Y.E.: Der galvanische Hautreflex und seine Brauchbarkeit in der klinischen Audiologie. Zentralblatt fur Hals-Nasen und Ohrenheilkunde. Bd. 50, 220, 1954.

18) Stewart, K.C.: "A new instrument for detect" ing the galvanic skin response. Journal of S. \& H. Disorders, 19: 1, p. 169 173, 1954. 19) Stewart, K.C.: Some basic consideration in applying the GSR technique to the measurement of auditory sensitivity. Journal of S. \& H. Disorders, 19: 1, p. 774 183, 1954. 20) Tato: Objective Audiometrie. Arch. Ohr-usw. Heilk. u.z. Hals usw. Heilk. Bd. 164, p. 447 486, $1954 . \quad$ 21) Goodhill, V., Rehman, I. and Brockman, S.: Objective skin resi. stance audiometry. Annals of Oto-Rhino-Laryng., 63: p. 32 38, 1954. 22) Portmann, M. and Portmann, C.: The value of various audiological tests in infants. Excerpt. Med. Sec. 11, 7, p. 276, 1954. .23) Bordley, J.E. and Haskins, H.L.: The role of the cerebrum in hearing. Ann. Oto. Rhino. \& Laryng., 64: p. 370 382, $1955 . \quad$ 24) Barr, B.: Pure tone audiometry for pre-school children. A clinical study with particular reference to children with impaired hearing. Acta Oto-Laryng. Suppl. 121, 1955. 25) Goldstein, R. Polito-Castro, Sara, B. Daniels, J.T.: Difficulty in conditioning elect-. rodermal responses to tone in normally hearing children. Journal of S. \& H. Disorders, 20: 1, p. 26 34, 195.5. 26) Harriet, L. and Haskins, A.M.: Differential diagnosis of hearing problems of adult patients. Laryngoscope 66: 6, p.658 666, 1956. 27) Portmann, $M$. and Portmann, C.: Die Bedeutung der objectiven Audiometric in der klinischer Otologie. Zentralblatt fur Hals-Nasen und Ohrenheilkunde, Bd. 55, 307, $1956 . \quad$ 28) Bordley, J.E.: An evalution of the psychogalvanic skin resistance technique in audiometry. Laryngoscope $66: 9, p$, 1162 1185, 1956. 29) Maspetiole, R., Pigement, $M$. and Tronche, $R$.: Information by objective audiometry using the psycho-galvanic reflex. (PGR) Excerpt. Med. Sec 11:9, p. 27, 1956. 30) Benicioline, F. and Fraccaroli, L.: Conditional reflex as a test for the simulation of deafness. Excerpt. Med. Sec. 11: 9, p. 175, $1956 . \quad$ 31) Rosen, J.: The place of GSR audiometry in work with yonng children. The Volta Reviw 58:9, 1956.132$)$ Goldstein, R.: Effectiveness of conditioned electrodermal responses (EDR) in measureing pure-tone thresholds in cases of non organic hearing loss. Laryngoscope 66:2, p. 119 130, 1956. 33) Statten, $P$.: Pure tone audiometry in young children, psychogalvanic skin resistance and peep-show: Annals Oto. Rhino. \& Laryng. 65: 2, p. 511 534, 1956. 34) Goldstein, R. and Withrow, F.B.: An electrophysiologic procedure for determination of auditory threshold in children. Laryngoscope $68: 9$, p. 1674 1699, 1958. 35) Schulz. E.: Der Lichtreiz bei der psychogalvanischen Reflexaudiometrie. Arch. Ohren, Nasen und Kehlkopf Heilkunde, Bd. 172, 553 559, 1958 . 36) 森本, 志井田: 他覚的聴力検査法の経験 (第1 報), 耳睤咽喉科臨椺, 45 潦, 2 号, 昭 27 . 37) 島：私共の他覚的オーデ

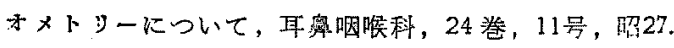
38）清水，管野，濑川：PGSR-Audiometry K開す

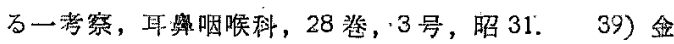

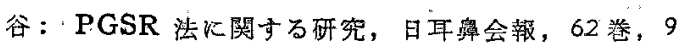
号，炤 34. 40) 小西，他：Psych-galvanic-skinreaction に上る聴力倹盗法の険討，Audiology 1：1， 1958. 41) 江崎：采件反射に上る聴覚検查の研究, 


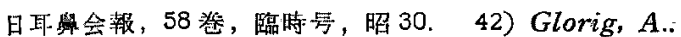
Malingering. Annals of Oto-Laryng. 63, p. 3, 802 -815, 1954. 43) Irwin, J.A. and Shreve, A.R.: Hearing and language evalution with hard of hearing children. Arch. of Otolaryng. 59: p. 186 191, 1954. 44) Marcus, R.E. and Gibbes, E.L.. Hearing and speeh problem in children observation and use of electroencephalography. Arch. Otolaryng. $53: 2$, p. $134 \sim 146,1951 . \quad 45)$ Froeschels, E.: Testing the hearing of young children. Arch. Otolaryng. 43: p.93 98, 1946.4 46) Froeschels, E. and Beebe, H.: Testing the hearing newbone infant. Arch. Otolaryng. 44: p. 710 714, 1949.

47) Wedenberg, E.: Audiometry tests on newbone infants. Acta Oto-Laryng. 46:5, p. 446 461, 1956. 48) Wishart, D.E.S.: The hard of hearing infant. Annals of Oto-Rhino-Laryng. 63: p.378 393, 1954. 49) Unger, M.: Objective measurement of hearing. Arch. Otolaryng. 29: p. 621 623, 1939. 50) Gidoll, S.H.: Quantitative determination of hearing to audiometric frequencies in the electroencephalogram: A preliminary report. Arch. Otolaryng. 56: 5, p.597 601, 1952. 51) Derbyshire, A.J. and Mc Dermott, M.: Further contribution to the EEG method of evaluating auditory function. Laryngoscope 68: 3. p. 558 570, 1958.

52) Aubert, M. et Martin, P.: Electro-encephalographic and audiometric study of deafmutism. Excerpt. Med. Sec 11, 4: 331, 1951. 53) Yamamoto, H., Nishikawa, H. Nagata, M. and Itakura, S.: The objective hearing tast in young children and deafness. Nagoya J. of M.S. 6: 2, 1953. 54)

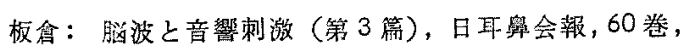
6 号, 炤 32. 55) 奉原, 他：脳波に上る聴力測定に ついて, 脳神経領域, 7 巻, 2 号, 眧 29 . 56) 浅輸 :

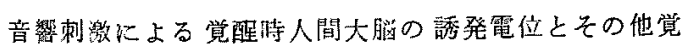

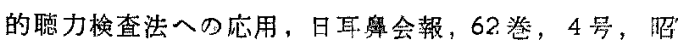

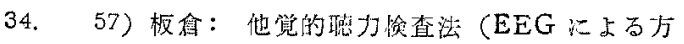
法) Audiology，2：2，1959，58）河村, 他：脳波 に上る他筧的聴力检查, Audiology, 2:2,1959. 59). Dix, M.R. and Hallpike, C.S.: The peep-show, a new technique for pure tone audiometry in young. children. Brit. Med. J. 115: p. 719 723, 1947. 60) Guilford, F.R. and Haug, C.O.: Diagnosis of deafness in the very young child. Arch. Otolaryng. 55: 2, p. 101 106, 1952. 61) Siegenthaler, B.M. and Kaplan, H.: A comparison of picture response and hand-raising techniques for pure tone audiometry with young children. Laryngoscope 68: 3, p. 548 558, 1958. 62) Meyerson, L.: Hearing. for speech in children: A verbal audiometric test. Acta Oto-Laryng. Supp. 128, 1956.63$)$ 竹内: 小胃の聴力䘳查法，日耳舆会郝，59巻，1号，1956. 64) 花風：Play audiometryによる奻紧の正常聴力に ついて, 日耳率会報, 60 癸， 7 号, 昭 32 . 65) 服部:

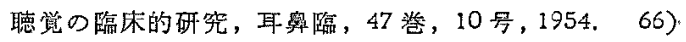
渡部：小児聴力検查法の研究，日耳學会報，62巻，7 号, 昭 34 67) Shimizu, FH. and Nakamura, F.: Pure tone audiometry in children lantern-slides. test. Annals Oto-Rhino-Laryng. 66: p. 392 398, 1957.

稿を䅂るにあたり，終始御愁切な御指導と御校閲 を戴いた恩師中村教授に心より感謝の意を表しな

ナまた本研究のための装置の作装を扮願いした亦 长一光氏，および御喔力を戴いた教室員の方々に謝 意老表します

本詇文の要旨は，日耳率関東地方会第 365 回例会 に和いて哞筡した。

（原穆到着=眧和 35.4 .9 日一急載） 